\title{
Peertechz
}

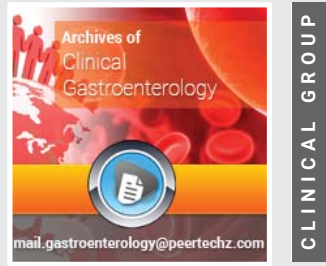

\section{Intravenous use of}

\section{Dexmedetomidine for}

\section{Attenuation of Hemodynamic}

Stress Response to

\section{Laryngoscopy and}

\section{Endotracheal Intubation}

\section{in Contrast to Intravenous}

Lignocaine

\section{Boksh SZ and Faruquzzaman*}

Chittagong Medical College Hospital, Chittagong, Bangladesh
Received: 12 April, 2018

Accepted: 08 December, 2020

Published: 09 December, 2020

*Corresponding author: Faruquzzaman, Chittagong Medical College Hospital, Chittagong, Bangladesh, E-mail: drfaruquzzaman@yahoo.com

Keywords: Dexmedetomidine; Hemodynamic stress response; Intubation; Laryngoscopy; Lignocaine

https://www.peertechz.com

\section{Check for updates}

\section{Abstract \\ Background: In the very recent studies it has been reflected that direct laryngoscopic endotracheal tube intubation following induction of anaesthesia is invariably associated reflex sympathoadrenal discharge with changes in hemodynamic stress response.}

Objective: The main objective of this Randomized Controlled Clinical Trial (RCT) is to compare the efficacy of intravenous use of dexmedetomidine in relation to dexmedetomidine in attenuating the hemodynamic response to laryngoscopy and intubation.

Study design: This study was conducted as a Randomized Controlled Clinical Trial (RCT) in Sir Salimullah Medical College, Mitford Hospital, Dhaka, Bangladesh with a total of 150 patients of elective surgery under general anaesthesia. Patients were divided into two groups on the basis of systemic random sampling, group D (dexmedetomidine group) and group L (lignocaine group) with 75 and 75 patients in respective groups.

Results: Mean \pm SD of age were $42.4 \pm 5.459$ and $40.8 \pm 9.975$ years respectively in group D \& L. And Majority (54.7\%) patients in group D were male, whereas in group L, it was $46.7 \%$. Relatively smooth and more stable changes were observed in systolic, diastolic and Mean Arterial Pressure (MAP) following intravenous infusion of dexmedetomidine in contrast intravenous infusion of lignocaine in response to laryngoscopy and endotracheal intubation. The incidence of hypertension was $2.0 \%$ (03) and $6.7 \%(05)$ in cases of Group D and Group L respectively. Tachycardia was found in $6.7 \%(05)$ and $12.0 \%(05)$ in respective group. The incidence of hypotension, bradycardia and arrhythmia was nil in this study.

Conclusion: Dexmedetomidine attenuates the hemodynamic stress response to laryngoscopy and intubation more effectively compared with lignocaine without any deleterious effects. Furthermore, dexmedetomidine decreases dose of thiopentone for induction of anaesthesia. 


\section{Introduction}

Direct laryngoscopy and endotracheal intubation following induction of anaesthesia is almost always associated with hemodynamic changes due to reflex sympathetic discharge. This increased sympathoadrenal activity may result in hypertension, tachycardia, and arrhythmias [1-3]. Transitory hypertension and tachycardia may predispose to the development of pulmonary edema [4] and myocardial insufficiency.

Various agents such as opioids [5] beta adrenergic blockers $[6,7]$ calcium channel antagonists [8] and clonidine [9] have been used to blunt the hemodynamic response to laryngoscopy and intubation, but they all had limitations. Intravenous (IV) lignocaine is one of the oldest, cheapest and most easily available drug used for attenuation of hemodynamic response to laryngoscopy and intubation [10-15].

Dexmedetomidine is a new alpha-2 adrenergic agonist having 8-times more affinity for alpha-2 adrenoceptors as compared with clonidine. Pre-treatment with dexmedetomidine attenuates hemodynamic response to laryngoscopy and intubation [16-21].

The present study was undertaken to compare the efficacy of $1.5 \mathrm{mg} / \mathrm{kg}$ of IV lignocaine and $1 \mathrm{mcg} / \mathrm{kg}$ of dexmedetomidine IV infusion in attenuating the hemodynamic response to laryngoscopy and intubation.

\section{Materials and methods}

This Randomized Controlled Clinical Trial (RCT) was conducted in Sir Salimullah Medical College, Mitford Hospital, Dhaka, Bangladesh with a total of 150 patients of elective surgery under general anaesthesia. Patients were divided into two groups on the basis of systemic random sampling, group D (dexmedetomidine group) and group L (lignocaine group) with 75 and 75 patients in respective groups. Group L received 1.5 $\mathrm{mg} / \mathrm{kg}$ of lignocaine intravenous (IV) and group D received 1 $\mathrm{mcg} / \mathrm{kg}$ of dexmedetomidine as IV infusion. Thiopentone was given until eyelash reflex disappeared, and intubation was facilitated with succinylcholine. Anaesthesia was maintained with 33:66 oxygen: Nitrous oxide, isoflurane, and vecuronium. Hemodynamic parameters were recorded during the basal period, preinduction, after induction, during intubation, 1 min, $3 \mathrm{~min}, 5 \mathrm{~min}$, and $10 \mathrm{~min}$ after intubation. $\mathrm{P}<0.05$ was considered as statistically significant.

\section{Results}

Demographic characteristic of the study population suggests that mean \pm SD of age were $42.4 \pm 5.459$ and $40.8 \pm$ 9.975 years respectively in group D \& L. Average weight was 65.0 and $69.5 \mathrm{~kg}$ respectively in both group. Majority (54.7\%) patients in group D were male, whereas in group L, it was 46.7\% (Figure 1).

Figure 2 shows mean \pm SD of systolic blood pressure (SBP) at different phases which suggests that change in systolic blood pressure (SBP) is more even and smooth in case of Group D in contrast to group L. (SBP) remains relatively stable in Group D. $P$ values suggest insignificant result here statistically (>0.05).

Comparative results of Diastolic Blood Pressure (DBP) in both groups are represented in Figure 3. DBP change is relatively smooth in Group D in contrast to group L. P values are also insignificant here (>0.05).

Mean arterial blood pressure (MAP) in different phases are depicted in Figure 4. In case of Group D, MAP is more stable

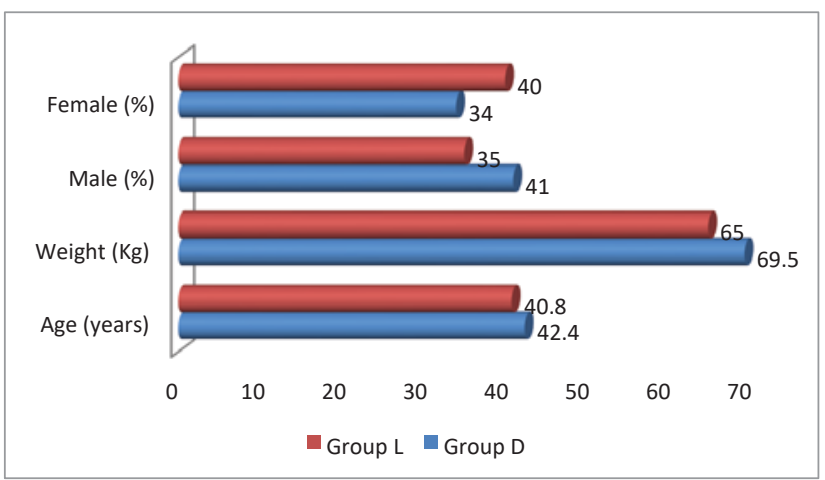

Figure 1: Demographic data and type of surgeries.

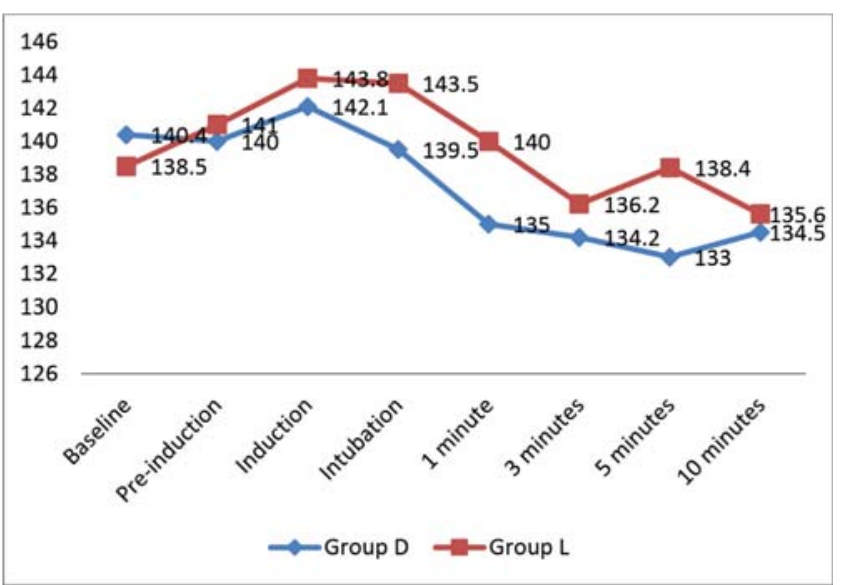

Figure 2: Comparison of mean SBP in both groups in various intervals.

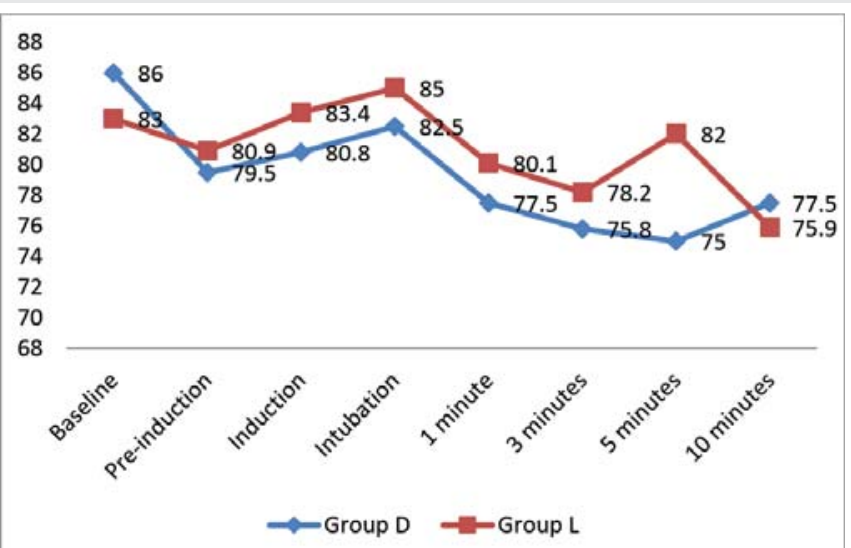

Figure 3: Comparison of mean DBP in both groups in various intervals. 
in relation to Group L especially after intubation. Smooth change in MAP is observed following intravenous infusion of dexmedetomidine in contrast intravenous infusion of lignocaine.

Changes in Heart Rate (HR) at different phases in both groups are tabulated in Figure 5. Heart rate fluctuates more with the use of lignocaine than dexmedetomidine following intubation. Smooth changes are observed in Group D than Group L. P-values are statistically insignificant here.

The incidence of hypertension was $2.0 \%$ (03) and 6.7\% (05) in the respective groups. Tachycardia was in $6.7 \%$ (05) cases of Group D whereas in Group L, it was $12.0 \%$ (09). Incidence of hypotension, bradycardia and arrhythmia was nil, observed in this study, though P-value is statistically insignificant here for this observation (Table 1).

120

100

80

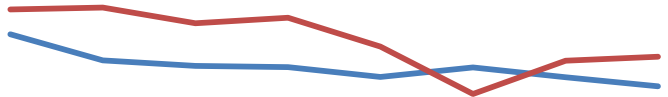

60

40

20

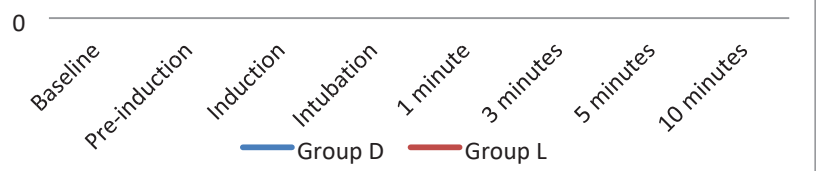

Figure 4: Comparison of mean MAP in both groups in various intervals.

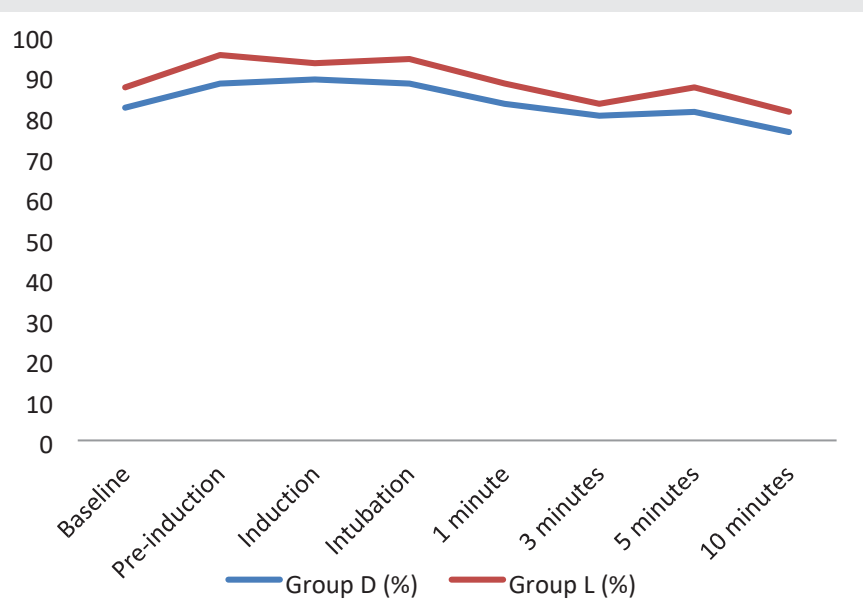

Figure 5: Comparison of mean HR in both groups in various intervals.

Table 1: Comparison of adverse haemodynamic responses in both groups.

\begin{tabular}{|c|c|c|c|}
\hline Adverse response & Group $\mathbf{D ,} \boldsymbol{n}(\%)$ & Group $\mathbf{L}, \boldsymbol{n}(\%)$ & $\boldsymbol{p}$ value \\
\hline Hypertension & $03(2.0 \%)$ & $05(6.7 \%)$ & \\
\hline Hypotension & $00(0.0 \%)$ & $00(0.0 \%)$ & \\
\hline Tachycardia & $05(6.7 \%)$ & $09(12.0 \%)$ & \multirow{2}{*}{0.5830} \\
\hline Bradycardia & $00(0.0 \%)$ & $00(0.0 \%)$ & \multirow{2}{*}{} \\
\hline Arrhythmia & $00(0.0 \%)$ & $00(0.0 \%)$ & \\
\hline
\end{tabular}

\section{Discussion}

Laryngoscopy and endotracheal intubation are considered as the most critical events during general anaesthesia as they provoke transient but marked sympathoadrenal response manifesting as hypertension and tachycardia [1-3]. many drugs have been tried by various authors for blunting hemodynamic responses to laryngoscopy and intubation [6-9] but all such manoeuvre's had their own limitations. Lignocaine was used in several studies for attenuation of the stress response [1015]. Lignocaine is one of the cheapest and safest drugs used in many centres to attenuate stress response to intubation.

Alpha-2 adrenergic drugs, such as clonidine or dexmedetomidine, attenuate these potentially harmful cardiovascular reactions during laryngoscopy and intubation. Dexmedetomidine is the new alpha- 2 against having 8-times more affinity for alpha-2 adrenoceptors as compared with clonidine. Dexmedetomidine offers a unique pharmacological profile with sedation, sympatholysis, analgesia, opioid and anaesthetic sparing effect, cardiovascular stability and with great advantage to avoid respiratory depression [2226].

The dose of lignocaine used in our study was $1.5 \mathrm{mg} / \mathrm{kg}$ IV given 3 min before intubation. Several authors [10,11,15] have concluded that $1.5 \mathrm{mg} / \mathrm{kg}$ of lignocaine suppresses stress response to intubation when given 3 min before intubation. The dose of dexmedetomidine used in our study was $1 \mathrm{mcg} /$ $\mathrm{kg}$ diluted in $100 \mathrm{ml}$ of normal saline and infused over 10 min. Several authors $[16,21]$ have used $0.5-1 \mathrm{mcg} / \mathrm{kg}$ of dexmedetomidine to attenuate stress response to intubation. Following infusion of dexmedetomidine, there was $11 \%$ reduction in $\mathrm{HR}$ and $9 \%$ reduction in MAP and the observations are similar to the observations made in other studies and can be explained on the basis of decreased central nervous system sympathetic activity $[16,17,20,27]$ Few authors $[18,21]$ noted a significant fall in HR in the dexmedetomidine group and an insignificant fall in MAP.

All patients in group $L$ had sedation score 2 in pre-induction period. This was due to injection midazolam and injection tramadol used as premedication. Most of the patients in group D had sedation score 3 (responding to verbal commands). None of the patients in group D had respiratory depression or fall in SpO2. Several authors $[17,20,22,28]$ have reported that dexmedetomine infusion produces sedation which mimics normal sleep, patients are arousable to verbal commands, and it lacks respiratory depression. These properties make dexmedetomidine a better choice of sedation for awake fibreoptic intubation, intensive care unit, post-anaesthesia care unit, magnetic resonance imaging and awake craniotomy [25].

The dose of thiopentone required for induction of anaesthesia was significantly lower in group D compared to group L. Keniya, et al. [17] Scheinin, et al. [19] and Bajwa, et al. [20] reported decreased thiopentone requirement for induction of anaesthesia in the dexmedetomidine group. Lignocaine did not effectively attenuate hemodynamic response to

Citation: Boksh SZ, Faruquzzaman (2020) Intravenous use of Dexmedetomidine for Attenuation of Hemodynamic Stress Response to Laryngoscopy and Endotrachea Intubation in Contrast to Intravenous Lignocaine. Arch Clin Gastroenterol 6(3): 077-081. DOI: https://dx.doi.org/10.17352/2455-2283.000085 
laryngoscopy and intubation. Few authors $[12,14]$ reported that the lignocaine fails to attenuate hemodynamic response, and our observations are in accordance with them.

Compared to lignocaine, dexmedetomidine at a dose of 1 $\mathrm{mcg} / \mathrm{kg}$ significantly attenuated hemodynamic response to laryngoscopy and intubation but could not obtund it completely. Several authors [16-21] reported that dexmedetomidine at a dose of $0.5-1 \mathrm{mg} / \mathrm{kg}$ significantly attenuated hemodynamic response to intubation but did not obtund it completely, and our observations are in accordance with them.

None of the patients had bradycardia or hypotension requiring intervention in group D. Dexmedetomidine was administered as an infusion over $10 \mathrm{~min}$ to prevent bradycardia and hypotension associated with a bolus dose [26].

\section{Limitation}

Effect was not seen in hypertensive and cardiac patients, was one of the most important limitations of this RCT. It will be more useful to study in high-risk hypertensive and cardiac patients which we could not study as we did not have invasive blood pressure monitoring and advanced cardiac setup in our institute. Also plasma catecholamine levels, which is an objective means of measuring hemodynamic stress response was not measured in our study.

\section{Conclusion}

Dexmedetomidine $1 \mathrm{mcg} / \mathrm{kg}$ IV as $10 \mathrm{~min}$ infusion attenuates the hemodynamic stress response to laryngoscopy and intubation more effectively compared to lignocaine $1.5 \mathrm{mg} / \mathrm{kg}$ IV without any deleterious effects. Furthermore, dexmedetomidine decreases dose of thiopentone for induction of anaesthesia.

\section{References}

1. Stoelting RK (1978) Blood pressure and heart rate changes during shortduration laryngoscopy for tracheal intubation: Influence of viscous or intravenous lidocasine. Anesth Analg 57: 197-199. Link: Link: https://bit. ly/3qCbICo

2. Prys-Roberts C, Greene LT, Meloche R, Foëx P (1971) Studies of anaesthesia in relation to hypertension. II. Haemodynamic consequences of induction and endotracheal intubation. $\mathrm{Br} \mathrm{J}$ Anaesth 43: 531-547. Link: https://bit.ly/2ln0i4d

3. Barak M, Ziser A, Greenberg A, Lischinsky S, Rosenberg B (2003) Hemodynamic and catecholamine response to tracheal intubation: Direct laryngoscopy compared with $\mathrm{fi}$ beroptic intubation. J Clin Anesth 15: 132-136. Link: https://bit.ly/3gj4v5H

4. Fox EJ, Sklar GS, Hill CH, Villanueva R, King BD (1977) Complications related to the pressure response to endotracheal intubation. Anaesthesiology 47: 524525. Link: https://bit.ly/3IRAvPh

5. Dahlgren N, Messeter K (1981) Treatment of stress response to laryngoscopy and intubation with fentanyl. Anaesthesia 36: 1022-1026. Link: https://bit.ly/2VNd8fb

6. Figueredo E, Garcia-Fuentes EM (2001) Assessment of the efficacy of esmolol on the haemodynamic changes induced by laryngoscopy and tracheal intubation: A meta-analysis. Acta Anaesthesiol Scand 45: 1011-1022. Link: https://bit.ly/3qAjn4h
7. Singh SP, Quadir A, Malhotra P (2010) Comparison of esmolol and labetalol, in low doses, for attenuation of sympathomimetic response to laryngoscopy and intubation. Saudi J Anaesth 4: 163-168. Link: https://bit.ly/3mQMMEY

8. Mikawa K, Nishina K, Maekawa N, Obara H (1996) Comparison of nicardipine, diltiazem and verapamil for controlling the cardiovascular responses to tracheal intubation. Br J Anaesth 76: 221-226. Link: https://bit.ly/3qDb4o6

9. Mikawa K, Nishina K, Maekawa N, Takao Y, Asano M, et al. (1995) Attenation of the catecholamine response to tracheal intubation with oral clonidine in children. Can J Anaesth 42: 869-874. Link: https://bit.ly/3mMT6NP

10. Splinter WM, Cervenko F (1989) Haemodynamic responses to laryngoscopy and tracheal intubation in geriatric patients: Effects of fentanyl, lidocaine and thiopentone. Can J Anaesth 36: 370-376. Link: https://bit.ly/37Azztq

11. Abou-Madi MN, Keszler H, Yacoub JM (1977) Cardiovascular reactions to laryngoscopy and tracheal intubation following small and large intravenous doses of lidocaine. Can Anaesth Soc J 24: 12-19. Link: https://bit.ly/3owLWxy

12. Miller CD, Warren SJ (1990) IV lignocaine fails to a attenuate the cardiovascular response to laryngoscopy and tracheal intubation. $\mathrm{Br} \mathrm{J}$ Anaesth 65: 216-219. Link: https://bit.ly/3qubPQq

13. Hamill JF, Bedford RF, Weaver DC, Colohan AR (1981) Lidocaine before endotracheal intubation: Intravenous or laryngotracheal? Anaesthesiology 55: 578-581. Link: https://bit.ly/2VMXxwd

14. Wilson IG, Meiklejohn BH, Smith G (1991) Intravenous lignocaine and sympathy o adrenal responses to laryngoscopy and intubation. The effect of varying time of injection. Anaesthesia 46: 177-180. Link: https://bit.ly/2LjfqRv

15. Tam S, Chung F, Campbell M (1987) Intravenous lidocaine: optimal time of injection before tracheal intubation. Anesth Analg 66: 1036-1038. Link: https://bit.ly/3INxBeB

16. Menda F, Köner $O$, Sayin $M$, Türe $H$, Imer $P$, et al. (2010) Dexmedetomidine as an adjunct to anesthetic induction to a enuate hemodynamic response to endotracheal intubation in patients undergoing fast-track CABG. Ann Card Anaesth 13: 16-21. Link: https://bit.ly/3osI9kU

17. Keniya VM, Ladi S, Naphade R (2011) Dexmedetomidine attenuates sympathoadrenal response to tracheal intubation and reduces perioperative anaesthetic requirement. Indian J Anaesth 55: 352-357. Link: https://bit.ly/39NRCiL

18. Sulaiman S, Karthekeyan RB, Vakamudi M, Sundar AS, Ravullapalli $\mathrm{H}$, et al. (2012) The effects of dexmedetomidine on attenuation of stress response to endotracheal intubation in patients undergoing elective off -pump coronary artery bypass grafting. Ann Card Anaesth 15: 3943

19. Scheinin B, Lindgren L, Randell T, Scheinin H, Scheinin M (1992) Dexmedetomidine attenuates sympathoadrenal responses to tracheal intubation and reduces the need for thiopentone and preoperative fentanyl. $\mathrm{Br}$ J Anaesth 68: 126-131. Link: https://bit.ly/2LgfeSU

20. Bajwa SJ, Kaur J, Singh A, Parmar S, Singh G, et al. (2012) Attenuation of pressor response and dose sparing of opioids and anaesthetics with pre-operative dexmedetomidine. Indian J Anaesth 56: 123-128. Link: https://bit.ly/3grPKO

21. Pipanmekaporn $T$, Punjasawadwong $Y$, Charuluxananan $S$, Lapisatepun W, Bunburaphong P (2013) The effect of prophylactic dexmedetomidine on hemodynamic disturbances to double-lumen endotracheal intubation: A prospective, randomized, double-blind, and placebo-controlled trial. Anesthesiol Res Pract 2013: 236089. Link: Link: https://bit.ly/33RUcAu

22. Hall JE, Uhrich TD, Barney JA, Arain SR, Ebert TJ (2000) Sedative, amnestic and analgesic properties of small-dose dexmedetomidine infusions. Anesth Analg 90: 699-705. Link: https://bit.ly/36NMMjv

23. Ebert T, Maze M (2004) Dexmedetomidine: Another arrow for the clinician's quiver. Anaesthesiology 101: 568-570. Link: https://bit.ly/360GGQ0

Citation: Boksh SZ, Faruquzzaman (2020) Intravenous use of Dexmedetomidine for Attenuation of Hemodynamic Stress Response to Laryngoscopy and Endotracheal Intubation in Contrast to Intravenous Lignocaine. Arch Clin Gastroenterol 6(3): 077-081. DOI: https://dx.doi.org/10.17352/2455-2283.000085 
24. Gerlach AT, Dasta JF (2007) Dexmedetomidine: An updated review. Ann Pharmacother 41: 245-252. Link: https://bit.ly/3gksBwM

25. Grewal A (2011) Dexmedetomidine: New avenues. J Anaesthesiol Clin Pharmacol 27: 297-302. Link: https://bit.ly/37JH2GK

26. Coursin DB, Coursin DB, Maccioli GA (2001) Dexmedetomidine. Curr Opin Crit Care 7: 221-226. Link: https://bit.ly/39Prlk8
27. Guler G, Akin A, Tosun Z, Eskitascoglu E, Mizrak A, et al. (2005) Singledose dexmedetomidine a enuates airway and circulatory reflexes during extubation. Acta Anaesthesiol Scand 49: 1088-1091. Link: https://bit.ly/33QdIOg

28. Carollo DS, Nossaman BD, Ramadhyani U (2008) Dexmedetomidine: A review of clinical applications. Curr Opin Anaesthesiol 21: 457-461. Link: https://bit.ly/37JHkxk

\section{Discover a bigger Impact and Visibility of your article publication with}

\section{Peertechz Publications}

\section{Highlights}

* Signatory publisher of ORCID

- Signatory Publisher of DORA (San Francisco Declaration on Research Assessment)

* Articles archived in worlds' renowned service providers such as Portico, CNKI, AGRIS, TDNet, Base (Bielefeld University Library), CrossRef, Scilit, J-Gate etc.

* Journals indexed in ICMJE, SHERPA/ROMEO, Google Scholar etc.

- OAI-PMH (Open Archives Initiative Protocol for Metadata Harvesting)

* Dedicated Editorial Board for every journal

* Accurate and rapid peer-review process

* Increased citations of published articles through promotions

* Reduced timeline for article publication

Submit your articles and experience a new surge in publication services (https://www.peertechz.com/submission).

Peertechz journals wishes everlasting success in your every endeavours.

Copyright: @ 2020 Boksh SZ, et al. This is an open-access article distributed under the terms of the Creative Commons Attribution License, which permits unrestricted use, distribution, and r eproduction in any medium, provided the original author and source are credited.

Citation: Boksh SZ, Faruquzzaman (2020) Intravenous use of Dexmedetomidine for Attenuation of Hemodynamic Stress Response to Laryngoscopy and Endotracheal Intubation in Contrast to Intravenous Lignocaine. Arch Clin Gastroenterol 6(3): 077-081. DOI: https://dx.doi.org/10.17352/2455-2283.000085 